\title{
THE EFFECTS OF TARGET SETTING ON TARGET COMMITMENT WITHIN THE DGT'S EMPLOYEES OF INDONESIA
}

\author{
Andri Marfiana \\ Universitas Pamulang \\ Dosen01991@unpam.ac.id
}

\begin{abstract}
The purpose of this study is to investigate the level of target commitment in the DGT and the role of target setting theory in effecting this. This research uses Kwan et al. (2013) goal-setting questionnaire. The sample comes from 165 employees of the Directorate General of Taxes (DGT), Indonesia. The result demonstrates that the level of target commitment within the DGT's employees is high. The effect of target setting factors shows that target clarity and the positive target setting processes positively related with target commitment, whereas target stress, target conflict, and dysfunctional effects of targets negatively related with target commitment. However, high level of target difficulty does not significantly relate to target commitment, strong possibility for moderator. In this study, it is argued that to have a high level of target commitment within the DGT's employees, It should have a target setting factors to effect this.
\end{abstract}

Keywords: Target setting, Target Commitment, Public sector, the Directorate General of Taxes, Indonesia.

\section{INTRODUCTION}

Recently, there has been growing interest in new public management (NPM) theory within the public sector throughout the world. The pioneer of using NPM in the public sector came from the Organisation for Economic Cooperation and Development (OECD) countries (Hood, 1995). One of the main ideas of NPM is performance management system based on target (Verbeeten and Spekle', 2015). Performance management system based on target is in common use in the private sectors management system. Hence, this means that the NPM is using the management system which was adopted from the private sector (Larbi, 1999).

Indonesia, as one of emerging countries in the world uses performance management system based on target in the public sector in order, to increase public trust. From many public sector institutions in Indonesia, this study chooses the Directorate General of Taxes (DGT) as a research subject because the DGT is 
the pioneer of performance management system based on the target (Indonesian Ministry of Finance, 2014). Moreover, the DGT has an important role in Indonesian Government as a taxes collector. $74.6 \%$ of government expenditures is financed by taxes (Indonesian Ministry of Finance, 2016). Hence, the achievement of tax revenue target by the DGT is very important and commitment from the DGT's employees to attain the target is also important.

There is a theory to measure performance based on target which is called goal-setting theory. This theory was initiated and developed by Locke and Latham. Over nearly four decades, goal-setting theory has been studied, using various methods, and recent concerns about goal-setting have generated a considerable body of research (Locke and Latham, 2002). In the development of goal-setting, Lee et al. (1991) categorised goal-setting into ten essential factors. These factors can measure the level of goal-setting compared to other factors (e.g. performance, goal commitment, and job satisfaction). Moreover, considerable enthusiasm has been generated by the discovery that, in order to attain the goal, goal commitment is important (Locke and Latham, 2002). Hence, this study wants to explore more about the relationship between goal-setting and goal commitment, especially within the DGT's employees.

Several studies have investigated the relationship between goal-setting factors and goal commitment. First, Klein et al. (1999) assessed the relationship between goal commitment and the goal-setting process. They found a positive relationship between goal-setting process and goal commitment. Secondly, Bipp and Kleingeld (2011) investigated the effect of some goal-setting factors on goal commitment. Their finding showed that only goal content affects goal commitment. Lastly, Kwan et al. (2013) tested the correlation between goalsetting factors and goal commitment. They discovered that goal clarity and the positive goal-setting processes positively correlated with goal commitment, whereas goal stress, goal conflict, dysfunctional effects of goals, and goal difficulty negatively correlated with goal commitment. Based on these results, the researcher intends to investigate further the relationship and the effect of target setting on target commitment within employees of the DGT. The use of the word 
"target" to change the term of "goal" is common, as this word is widely used within organisations (Yearta et al., 1995). Hence, the research in this study uses the word "target" to substitute the term of "goal", in order to adapt to the terminology used by the object on which the research is conducted.

The purpose of this research is to assess the level of target commitment in the DGT and the role of target setting theory in effecting this. In order to investigate it, this study aims to accomplish the following research objectives:

1. To observe the level of target commitment within the DGT's employees.

2. To examine the relationship between target setting factors (including target difficulty) and target commitment.

\section{LITERATURE REVIEW AND HYPOTHESIS DEVELOPMENT}

\section{The Goal Setting Theory}

Goal-setting theory is "a theory of motivation that explains what cause some people to perform better on work-related task than other" (Locke and Latham, 2013, p.3). Locke and Latham (2002) conducted the research to formulate a goal-setting theory for over nearly four decades and there are many more studies concerning goal-setting theory which have been conducted since 1960 (Mitchell and Daniels, 2003). Their research was based on the premise that conscious goals affect action (Ryan, 1970, cited in Locke and Latham, 2002). In the development of goal-setting theory in 1990, Locke and Latham (2002) found the two core findings were as follows:

a. The relationship between the degree of difficulty in goal-setting and performance. It was argued that more difficult kinds of goal will lead to higher performance, for example, Locke (1967) found that the participants with the highest goals had over $250 \%$ higher level of performance compared with the participants who had the easiest goals, and the relationship was linear. In another research, the relationship between task difficulty and performance was curvilinear, inverse function (Atkinson,1958, cited in Locke and Latham, 2002, p.705). This means that the highest level of effort generates from moderately 
difficult tasks and the lowest level of effort occurs when the task is very easy or very hard. However, this finding cannot compare with Locke's (1967) findings, because the term of task and goal difficulty are not similar and they can be measured separately (Locke and Latham, 2002). Furthermore, to support Locke's findings, Locke and Latham (1990), through their research, found that goal difficulty effect size (d) in meta-analyses ranged from 0.52 to 0.82. This means that the linear relationship between the degree of goal difficulty and performance was proved. Additional, meta-analysis was provided to support this linear relationship (Mento et al., 1987; Tubbs, 1986; Wood et al., 1987).

b. The effect of a specific goal. A specific, difficult goal, it is argued, will consistently lead to higher performance than abstract or vague goal, such as to do one's best (Locke, 1996; Locke and Latham, 2002; Locke and Latham, 2013). An abstract or vague goal will cause ambiguity in order to reach it and it will be subjective (Locke and Latham, 2013). Quantitative (increase sales by $15 \%$ ) and enumeration (the list of the target that must be attained) is the way by which a specific difficult goal can be achieved, because it will reduce variety in performance and motivate an individual to manage their performance (Locke, 1996). Many researchers support this hypothesis, such as Latham and Yukl (1975), Locke et al. (1981), and Steer and Porter (1974). For example, Locke et al. (1981) reported that 96\% (51 from 53) studies presented the advantage of the specific difficult goal. To support this assertion, Locke and Latham (1990) measured the effect size in meta-analysis and the range was from 0.42 to 0.80 . In other words, people will have better performance when the goal level is specific, rather than people being told "do-your-best", they will not do it.

The next finding in goal-setting theory is goal mechanisms. Locke and Latham (2002) stated that goal will impact on performance through four mechanisms. The first mechanism is a directive function: people tend to focus on and make an effort only with their goal-relevant activities and ignore goalirrelevant activities. This impact arises behaviourally and cognitively, for 
instance, Locke and Bryan (1969) found that people who were given feedback on their driving score in an automobile-driving task changed their performance only on the dimension on which a goal was set, not in other dimensions. The second mechanism is an effort; the difficult goal will lead to higher effort than low goals. These had been proved in a different task, such as a physical task using an exercise machine (Bandura and Cervone, 1983) and physiological effort (Sales, 1970). Summarily, proportion to the difficulty level of the goal is expanded and mobilised by an effort (Latham and Locke, 1975; Locke, 1968). Persistence is the third goal mechanism, in order to the time required to achieve a goal. It is argued that people with a specific difficult goal will work longer than people who had an easy or unclear goal (Locke and Latham, 2013). One research found that people who had easy goals stop working earlier than people who had high goals (Bavelas and Lee, 1978). Another research in a maze task claimed that participants with difficult goals worked longer to complete the maze than participants who had moderate, easy, and "do the best" goals (Huber, 1985). The last goal mechanism is knowledge or task strategy. In this goal mechanism, Locke and Latham (2002) found some summary in the list below:

- People automatically use their relevant knowledge and skill that they already had to attain a goal when faced with task goals. For example, Latham and Kinne (1974) found that the loggers who had to cut the logs as their goal was did not use an additional conscious plan in their effort and persisted until the goal was attained, because they will automatically use their knowledge and skill in their daily jobs.

- If the goal is related with a matter which does not use an automatical skill, people tend to use their experience from a same previously related context and apply it in the current situation. For instance, the truck drivers who had a goal to increase the weight of their trucks loads made some modification in their trucks so that they could better estimate the weight before they went to the weighing station (Latham and Baldes, 1975).

- People will become more involved in the planning process to develop a strategy to attain the goals when they have a new goal (Smith et al., 1990). 
- People with high self-efficacy are better than people who have low selfefficacy in developing an effective task strategy to achieve a goal (Latham et al., 1994). As people will find appropriate strategies to attain the goals, there will be a time lag between the assignment and the effect of the goal on performance (Smith et al., 1990).

- In the complex task, telling people to do their best sometimes leads to better strategies than urging people to have specific difficult performance goals (Early et al., 1989). This is because having specific difficult goals in the complex task will cause people to have tunnel vision, as discussed in the previous section.

\section{Goal Setting Factor}

To measure perception about the goal-setting programmes within the organisation, Locke and Latham (1984) developed 53 questionnaires, including the core goal attributes (specificity and difficulty), the related attributes, and the moderators. In the development, Lee et al. (1991) summarised Locke and Latham (1984) goal-setting questionnaires into ten meaningful factors, including supervisor support/participation, goal stress, goal efficacy, goal rationale, use of goal-setting in performance appraisal, tangible rewards, goal conflict, organisational facilitation of goal achievement, dysfunctional effects of goals, and goal clarity. This study uses these factors and goal difficulty as an addition from Kwan et al.'s (2013) to investigate the effect of target setting on target commitment within the DGT's employees.

\section{The Goal Commitment}

To achieve a goal, commitment is a very important factor, because goals cannot work as intended without commitment (Klein et al., 2013). Goal commitment is the attractiveness and expectancy of goal achievement (Bipp and Kleingeld, 2011). In other words, people's determination to attain a goal and an unwillingness to abandon it (Klein et al., 1999). In the relationship between goalsetting and performance, commitment is commonly used as a moderator (Locke 
and Latham, 2002). Moreover, Locke (1996) in his research, found that the most critical commitment to goals is when goals are specific and difficult. Furthermore, he did not specifically explain the relationship between goal-setting factors and goal commitment.

There was some research which concentrated on examining the relationship between goal-setting factors and goal commitment. One research, which was conducted by Klein et al. (1999), examined the relationship between goal commitment and the goal-setting process. They found that there was a positive relationship between goal commitment and performance, goal difficulty moderated goal commitment and performance relationship, positive relationship between goal commitment and goal process (feedback and participation or voice in the determination of goal). From their meta-analysis result, there was evidence that goal clarity is positively related to goal commitment and supervisor support positively related to goal commitment.

\section{The Goal-setting Within the DGT}

The presence of goal-setting that is discussed in the theory within the DGT is explained in the following discussion:

a. Supervisor support/Participation and goal rationale. This factor relates to the activity when the target is arranged. When the target is arranged, it has to meet the requirement which is agreeable. This means that the target has to be agreed by employee and supervisor before it is determined. Moreover, target setting is an agreement between supervisors and subordinates as well as considering the proposals from the organisation's performance manager. Hence, it will be processed where the supervisor, and the employee who has a target, discuss target determination. Therefore, this research tries to analyse this factor in the DGT.

b. Goal stress, goal efficacy, goal conflict, organisation facilitation of goal achievement, and dysfunctional effect of goals. Every employee in the DGT has his/her own target and he/she has their own perception for their target. 
Hence, this study tries to find these factors' levels in the DGT's employees to link with the goal-setting theory.

c. Use of goal-setting in performance appraisal and tangible rewards. These factors show in the assessment of performance result and evaluation phase on performance management framework. This process results in employee appreciation and employee restructure, for example, promotion for the best employee as a reward.

d. Goal clarity and goal difficulty. These factors fit with Key Performance Indicator (KPI) characteristic as a target: specific, measurable, realistic, and time-bound. Hence, this study will analyse these factors' level in the DGT and compare it with the present literature.

e. Goal commitment. This factor can measure the level of the DGT's employees' commitment to the employee commitment to the target statement.

The target within the DGT organisation is centralised and there are still issues surrounding the collection of tax revenue. Hence, this study will look at the target setting theory, in order to be able to identify what elements of this theory are present or missing, and so might be able to improve things in the DGT organisation.

\section{Hypothesis and Research Questions}

These study areas of investigation are intended to assess the level of target commitment in the DGT and the role of target setting theory in affecting target commitment. These findings from this research can also be analysed to identify where the organisation might be able to improve. To analyse this, this study adopts and develops Kwan et al.'s (2013) questionnaire. Hence, this research expects some relationship among these factors as the following hypotheses:

Hypothesis 1 : Supervisor support/participation is positively related to target commitment.

Hypothesis 2 : Target stress is negatively related to target commitment.

Hypothesis 3 : Target efficacy is positively related to target commitment.

Hypothesis 4 : Target rationale is positively related to target commitment. 
Hypothesis 5 : Use of target setting in performance appraisal is positively related target commitment.

Hypothesis 6 : Tangible rewards are positively related to target commitment.

Hypothesis 7 : Target conflict is negatively related to target commitment.

Hypothesis 8 : Organisational facilitation of target achievement is positively related to target commitment.

Hypothesis 9 : Dysfunctional effects of targets are negatively related to target commitment.

Hypothesis 10 : Target clarity is positively related to target commitment.

Hypothesis 11 : Target difficulty is negatively related to target commitment.

\section{RESEARCH METHOD AND DISCCUSSION}

\section{Research Method}

The research idea of this study is to assess the level of goal commitment in the DGT and the role of goal-setting theory in affecting this. The study hypotheses will then investigate the specific relationships that the theory posits between the elements of goal-setting theory and goal commitment, as discussed in the prior hypotheses. The researcher chooses this idea because the researcher works for the DGT and would like to make some contribution to the organisation. The target itself, crucial issues in the DGT institution and commitment to the target, are also necessary to attain the target. The result of this research might become input to improve the DGT management system in the future.

This study uses positivism philosophy in the research, because it uses existing theory in goal-setting and goal commitment to develop the hypotheses. Moreover, from existing theory, it uses quantitative data to analyse the hypotheses. Then, this study adopts and develops their method in its research and uses a different object to test the hypotheses.

This study uses the primary data collected method because it uses new information that has never been used before and the data was collected only for the purpose of this investigation. As mentioned before, this study uses quantitative 
data to analyse the hypotheses and the research question. Hence, to collect the primary quantitative data, the researcher uses a questionnaire as a tool.

There are three reasons why this study uses a survey to collect the data. First, the questionnaire is the most widely used for data gathering method in survey strategy, because the researcher can ask the same set of questions at the same time to many respondents (Saunders et al., 2016). Hence, it will become an efficient way to collect a large amount of data in the quantitative method. Secondly, this questionnaire adopts Kwan et al.'s (2013) survey to measure goalsetting and Klein et al.'s (2001) to measure goal commitment. Therefore, the researcher finds it easy to make a very structured questionnaire to measure each variable in the hypotheses. Third, the anonymous participant in the survey could lead to the honest answer and reduce the risk (Anderson, 2013). Hence, the researcher can have a better analysis in the relationship between the different variables. These all of advantages can overcome problems such as geographical distance with the respondents and difficulty in finding the right time to interview respondents. Thus, the researcher chooses the survey as the method of collecting the data.

The participants of this research are the employees of the DGT. The researcher chooses this respondent because the researcher works for this institution. Hence, the researcher will obtain easy access to the participants. The number of sample size is 165 of the DGT employees. It is a small sample size because the variables that are used in this research are not too many. The method for sampling is non-probability sampling method. Non-probability sampling method is a sampling procedure that does not give all the individuals in the population an equal chance of being included in the sample (Saunders et al., 2016). Moreover, the respondents come from different kinds of tax offices, job positions, levels of education, gender, experience, and monthly income. This research chooses these diverse because this demographic varaibles will represent the various employees in the DGT. Hence, the result will generate better analysis than research with a small variety of respondents. 
This research uses IBM SPSS statistic software to analyse the data from the questionnaire. The researcher uses this software because it is the most widely used by researchers who analyse quantitative data in their study. Moreover, SPSS can be used to generate large data rapidly, so that the researcher can rely on this software to analyse the data.

There are several steps to analyse the data. Firstly, the researcher generates the demographic findings. In this step, the researcher shows the percentage of every demographic variable. Hence, the data gives the information about the demographic composition and the possibility of it being used as the control variable. Secondly, the researcher measures the tendency of each variable. The researcher uses average mean to do this, as this method is the most reliable measure of central tendency (Verma, 2013). Next, the researcher tests the reliability of the questionnaire in every variable. The reason is because the questionnaire not only must be valid, but must also be reliable (Saunders et al., 2016). Many researchers commonly used Cronbach alpha to calculate internal consistency of the question (Saunders et al., 2016), as used in this study.

The next step in the findings is the correlation test. The researcher uses Pearson product-moment correlation coefficient for examining the correlation between independent variables and dependent variable. The researcher also tests the correlation between the demographic variables and target setting. The researcher uses ANOVA correlation for employee's position, type of tax office, and for gender use t-test to target commitment because they are categorical, not scale. Meanwhile, the researcher uses Spearman's correlation for the level of age, the level of education, the level of experience, and the level of income to target commitment because Spearman ranks order correlation as designed for use with ordinal level or ranked data (Pallant, 2005). Moreover, from these results, the researcher has information about which demographic variables can be used as control variables for examining the hypotheses. The correlation between two factors is significant if the significant value is less than $0.05(\mathrm{p}<0.05)$ (Pallant, 2005; Verma, 2013). 
After the correlation results are produced, the researcher uses linear regression to test the hypothesis questions and answer the research question in the SPSS programme. The researcher tests the hypothesis between every target setting factor and target commitment using the control variables which are generated from demographic correlation which shows significant correlation. For employee position as a control variable, the researcher turned these into dummy variables, with the manager as the reference category. Thus, in the discussion, the researcher could have a summary of hypotheses and research question.

The demographic findings show that the composition of participants is diverse and represents every kind of demographic criteria. The result also describes the real demographic of the DGT's employees. Hence, the researcher can use these demographic findings for control variable to test the hypotheses .

The descriptive analysis findings display that, if compared with the other factors, supervisor support/participation, self-efficacy, target difficulty, target clarity, target commitment, and use of target setting in performance appraisal have a high-level value of the average mean (positive). However, target stress, dysfunctional effects of targets, and target conflict have a low-level value of average mean (negative). Moreover, organisation facilitation of target achievement, target efficacy, tangible rewards, and target rationale have a medium level value of average mean (moderate). This study considers an average mean above 3.5 as a high average mean (Kim et.al, 2010). The results shown in the following table. 
Table 1

Descriptive analysis

\begin{tabular}{|l|r|}
\hline \multicolumn{1}{|c|}{ Variables } & Average Mean \\
\hline Supervisor Support/Participation & 3.98 \\
Target Stress & 2.65 \\
Target Efficacy & 3.38 \\
Target Rationale & 3.26 \\
Use of target setting in performance appraisal & 3.64 \\
Tangible Rewards & 3.29 \\
Target Conflict & 3.06 \\
Organisation facilitation of Target achievement & 3.46 \\
Dysfunctional effects of targets & 2.89 \\
Target Clarity & 3.70 \\
Target Difficulty & 3.73 \\
Self-Efficacy & 3.92 \\
Target Commitment & 3.69 \\
\hline
\end{tabular}

From the correlation analysis, the researcher finds that most of the target setting factors have a significant correlation with target commitment, except target difficulty.

The result also shows that the variables which have a positive effect on target also show a positive correlation with target commitment. However, the variables that cause the negative effect of the target also have a negative correlation with target commitment. The complete results show in Table 2. 
Table 2

Correlations

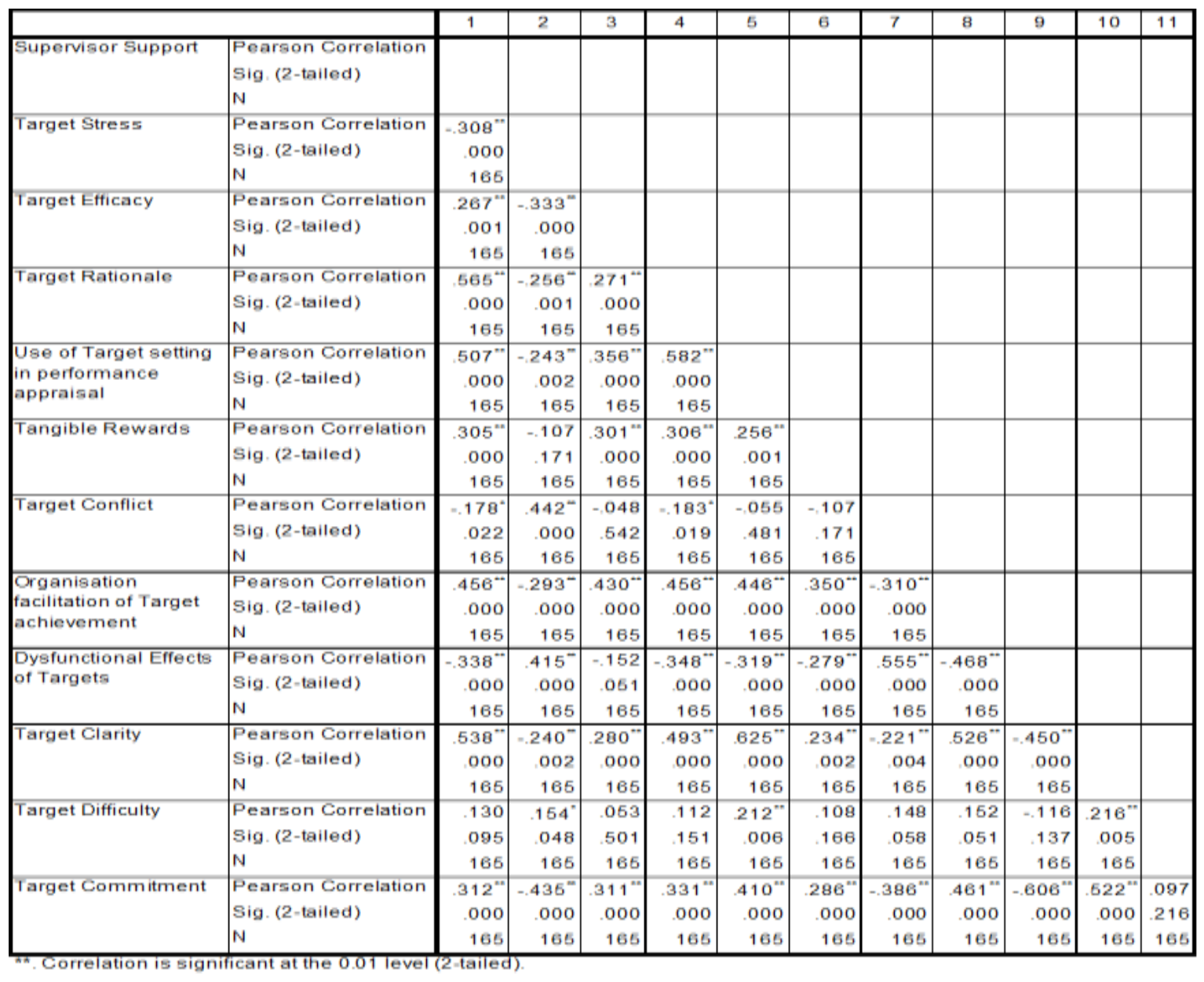

*. Correlation is significant at the 0.05 level (2-tailed)

Furthermore the correlation between demographic variables with target commitment has significant correlation only in employee position, the level of education, experience, and the level of income. Hence, these demographic variables are used as control variables to test the hypothesis. The figure shown in Table 3. 
Table 3

Correlation Between Demographic Variables With Target Commitment

\begin{tabular}{|l|c|c|}
\hline \multicolumn{2}{|c|}{} & Target Commitment \\
\hline Employee Position & Sig. & 0.000 \\
Tax Office Types & Sig. & 0.098 \\
Gender & Sig. & 0.192 \\
Age of Participants & Sig. & 0.223 \\
Education Level of Participants & Sig. & 0.025 \\
The Length of Service in the DGT & Sig. & 0.008 \\
Level of Monthly Income & Sig. & 0.035 \\
\hline
\end{tabular}

The researcher uses linear regression to examine the hypotheses. In examining the hypotheses, the researcher uses control variables based on the correlation result between demographic variables and target commitment. The regression result for testing the first hypothesis is shown in Table 4.

Table 4:

Relationship Between Supervisor Support/Participation and Target Commitment

\begin{tabular}{|c|c|c|c|c|}
\hline \multirow[t]{2}{*}{ Model } & \multicolumn{2}{|c|}{$\begin{array}{l}\text { Unstandardized } \\
\text { Coefficients }\end{array}$} & \multirow{2}{*}{\begin{tabular}{|c|}
$\begin{array}{c}\text { Standardized } \\
\text { Coefficients }\end{array}$ \\
Beta
\end{tabular}} & \multirow[t]{2}{*}{ Sig. } \\
\hline & $B$ & Std. Error & & \\
\hline (Constant) & 3.045 & .438 & & .000 \\
\hline Supervisor Support Participation & .235 & .059 & 284 & 0 \\
\hline Post=Functional (Tax Auditor, Land and Building Tax & 122 & 152 & 202 & \\
\hline Appraisal, and Computer Programmers) & .724 & .1500 & 100 & \\
\hline Post=Account Representative Reviewers'Objections & -593 & .160 & -516 & 0 \\
\hline Post=Other Subordinate Em ployee & -407 & 203 & -325 & .04 \\
\hline Education Level & .043 & .066 & .054 & .5 \\
\hline Experience & .102 & .052 & .183 & $05^{3}$ \\
\hline Income & -148 & 109 & -176 & 1 \\
\hline
\end{tabular}


Based on Table 4, there is a significant positive relationship between supervisor support/participation and target commitment with interaction from control variables $(\beta=0.284)$. From this result also, it can be seen that target commitment is decreased in functional, Account Representative, and other subordinates if compared with target commitment within manager position. Moreover, the adjusted R2 for this relationship is 0.19 . This means that supervisor support/participation helps to explain nearly $19 \%$ of the variance in respondents' scores on the target commitment scale. The findings also explain that in this case, only employee position has significant interaction and the others do not have significant relationship. Hence, based on the findings, the results support hypothesis 1 .

The analysis for the second hypothesis is displayed in Table 5. From Table 5, it can be seen that target stress is negatively significant related with target commitment $(\beta=-0.397)$. As with the result from Hypothesis 1 , the target commitment level for other employee position is lower than manager position. This model shows significant relationship for most all control variables besides the level of education. Furthermore, the adjusted R2 for this relationship is 0.245. This means target stress helps to explain $24.5 \%$ of the variance in respondents' scores on the target commitment scale. Thus, Hypothesis 2 is supported by these findings.

Table 5:

Relationship Between Target Stress and Target Commitment

\begin{tabular}{|c|c|c|c|c|}
\hline \multirow[t]{2}{*}{ Model } & \multicolumn{2}{|c|}{$\begin{array}{l}\text { Unstandardized } \\
\text { Coefficients }\end{array}$} & \multirow{2}{*}{$\begin{array}{c}\text { Standardized } \\
\text { Coefficients } \\
\text { Beta }\end{array}$} & \multirow[t]{2}{*}{ Sig. } \\
\hline & B & Std Error & & \\
\hline 1 (Constant) & 4.912 & 373 & & .000 \\
\hline Target Stress & -286 & .053 & -397 & .000 \\
\hline $\begin{array}{l}\text { Post=Functional (Tax Auditor, Land and Building Tax } \\
\text { Appraisal and Computer Programmers) }\end{array}$ & -.402 & .147 & -269 & .007 \\
\hline Post=Account RepresentativeiReviewers' Objections & -490 & .157 & -427 & .002 \\
\hline Post=Other Subordinate Employee & -.511 & .195 & -408 & .010 \\
\hline Education Level & .021 & .064 & .026 & .744 \\
\hline Experience & .115 & .050 & 207 & .024 \\
\hline Income & -.222 & .106 & -264 & .037 \\
\hline
\end{tabular}


Hypothesis 3: target efficacy is positively related to target commitment. The result in Table 6 shows that there is a significant positive relationship between target efficacy and target commitment $(\beta=0.241)$. Similar to both of the previous hypotheses, the control variables only have a significant relationship in employee position and the level of target commitment also shows the same pattern for employee position with the other hypotheses. Moreover, there is $16.2 \%$ (adjusted R2=0.162) variance of these two variables shared in this model. Hence, the findings support Hypothesis 3.

Table 6:

Relationship Between Target Efficacy and Target Commitment

\begin{tabular}{|c|c|c|c|c|}
\hline \multirow[t]{2}{*}{ Model } & \multicolumn{2}{|c|}{$\begin{array}{l}\text { Unstandardized } \\
\text { Coefficients }\end{array}$} & \multirow{2}{*}{$\begin{array}{c}\begin{array}{c}\text { Standardized } \\
\text { Coefficients }\end{array} \\
\text { Beta }\end{array}$} & \multirow[t]{2}{*}{ Sig. } \\
\hline & B & Std. Error & & \\
\hline (Constant) & 3.551 & 395 & & .000 \\
\hline Target Efficacy & 194 & .061 & 241 & .002 \\
\hline $\begin{array}{l}\text { Post=Functional (Tax Auditor, Land and Building Tax } \\
\text { Appraisal, and Computer Programmers) }\end{array}$ & -459 & 155 & -307 & .003 \\
\hline Post=Account Representative Reviewers' Objections $^{\prime}$ & -596 & .163 & -.519 & .000 \\
\hline Post=0ther Subordinate Em ployee & -485 & 205 & -387 & .019 \\
\hline Education Level & -.003 & .068 & -.004 & 965 \\
\hline Experience & .091 & .053 & .164 & .090 \\
\hline Income & -156 & 111 & -.186 & .161 \\
\hline
\end{tabular}

Hypothesis 4: target rationale is positively related to target commitment. Table 7 describes the result for this hypothesis. The findings show that there is a significant positive

relationship between target rationale and target commitment $(\beta=0.323)$. Differing from the other previous hypotheses, this model displays significant relationship for most of the control variables except the education level. However, the employee position and the level of income decrease the level of target commitment. Moreover, the adjusted R2 for this model is 0.214 (21.4\%). Hence, the findings support Hypothesis 4. 
Table 7:

Relationship Between Target Rationale and Target Commitment

\begin{tabular}{|c|c|c|c|c|c|}
\hline & \multirow[t]{2}{*}{ Model } & \multicolumn{2}{|c|}{$\begin{array}{l}\text { Unstandardized } \\
\text { Coefficients }\end{array}$} & \multirow{2}{*}{$\begin{array}{c}\begin{array}{c}\text { Standardized } \\
\text { Coefficients }\end{array} \\
\text { Beta }\end{array}$} & \multirow[t]{2}{*}{ Sig } \\
\hline & & B & Std Error & & \\
\hline \multirow[t]{8}{*}{1} & (Constant) & 3.531 & 367 & & .000 \\
\hline & Target Rationale & 214 & 046 & 323 & .000 \\
\hline & $\begin{array}{l}\text { Post=Functional (Tax Auditor, Land and Building Tax } \\
\text { Appraisal, and Computer Programmers) }\end{array}$ & -460 & .150 & -307 & .003 \\
\hline & Post=Account Representative/Reviewers' Objections & -680 & .157 & -591 & .000 \\
\hline & Post=Other Subordinate Em ployee & -.552 & .199 & -441 & 006 \\
\hline & Education Level & .030 & .065 & .038 & .646 \\
\hline & Experience & 114 & .052 & 205 & .028 \\
\hline & Income & -224 & 108 & -266 & .040 \\
\hline
\end{tabular}

Hypothesis 5: use of target setting in performance appraisal is positively related to target commitment. Based on Table 8 , there is a significant positive relationship between use of target setting in performance appraisal and target commitment $(\beta=0.383)$. The adjusted $\mathrm{R} 2$ for this model is $0.255(25.5 \%)$. The level of target commitment level in employee position shows a similar pattern to Hypotheses 1, 2, and 3. Thus, the findings support Hypothesis 5.

Table 8:

Relationship Between Use of target setting in performance appraisal and Target

Commitment

\begin{tabular}{|c|c|c|c|c|}
\hline \multirow[t]{2}{*}{ Model } & \multicolumn{2}{|c|}{$\begin{array}{l}\text { Unstandarized } \\
\text { Coefficients }\end{array}$} & \multirow{2}{*}{$\begin{array}{c}\begin{array}{c}\text { Standardized } \\
\text { Coefficients }\end{array} \\
\text { Beta }\end{array}$} & \multirow[t]{2}{*}{$\operatorname{sig}$} \\
\hline & B & Std Error & & \\
\hline 1 (Constant) & 2.996 & 390 & & 000 \\
\hline Use of target setting in performance apprais al & 329 & 059 & 383 & .000 \\
\hline $\begin{array}{l}\text { Post=Functional (Tax Auditor, Land and Building Tax } \\
\text { Appraisal, and Computer Program mers) }\end{array}$ & -421 & .146 & -281 & .005 \\
\hline Post=Account Representative/Reviewers' Objections & -643 & .153 & -560 & 000 \\
\hline Post=Other Subordinate Em ployee & -510 & 194 & -407 & 009 \\
\hline Education Level & 054 & 064 & 068 & 394 \\
\hline Experience & 084 & .050 & 151 & 099 \\
\hline Income & -215 & 105 & -255 & 043 \\
\hline
\end{tabular}

Hypothesis 6: tangible rewards are positively related to target commitment. The relationship between these variables based on Table 9 is significantly positive $(\beta=0.252)$, with adjusted $R 2=0.172(17.2 \%)$. The level of target commitment for control variable is only significant in employee position, 
whereby managers seem to be more committed than other employees, and has a similar pattern to the other hypotheses. In concluding, these findings support Hypothesis 6.

Table 9:

Relationship Between Tangible Rewards and Target Commitment

\begin{tabular}{|c|c|c|c|c|}
\hline \multirow[t]{2}{*}{ Modet } & \multicolumn{2}{|c|}{$\begin{array}{l}\text { Unstandardzod } \\
\text { Coefficients }\end{array}$} & \multirow{2}{*}{$\begin{array}{c}\text { Standardized } \\
\text { Coefficients } \\
\text { Beta } \\
\end{array}$} & \multirow[t]{2}{*}{ Sig. } \\
\hline & B & Std Error & & \\
\hline (Constant) & 3.599 & 382 & & 000 \\
\hline Tangible Rewards & 162 & 046 & 252 & 001 \\
\hline $\begin{array}{l}\text { Post=Functional (Tax Auditor, Land and Bullding Tax } \\
\text { Appraisal, and Computor Program ors) }\end{array}$ & -470 & 154 & -314 & 003 \\
\hline Post-Account Representative R $^{-}$eviewers' Objections & -623 & 161 & -542 & Doo \\
\hline Post=Other Subordinate Employee & -497 & 204 & -397 & 016 \\
\hline Education Lavel & 019 & 067 & 024 & 778 \\
\hline Experience & 100 & 053 & 180 & 061 \\
\hline fincome & -158 & 110 & -188 & .154 \\
\hline
\end{tabular}

Hypothesis 7: target conflict is negatively related to target commitment. Table 10 shows the relationship between these variables is significantly negative $(\beta=-0.338)$. This model also shows significant relationship for two control variables (employee position and experience). The level of target commitment also decreases for other employee positions compared to manager position similar to the other hypotheses' results. Moreover, adjusted R2 for this model is 0.214 $(21.4 \%)$. Hence, these findings are in line with the hypothesis.

Table 10:

Relationship Between Target Conflict and Target Commitment

\begin{tabular}{|c|c|c|c|c|}
\hline \multirow[t]{2}{*}{ Modal } & \multicolumn{2}{|c|}{$\begin{array}{l}\text { Unsfandardizod } \\
\text { Coefficients }\end{array}$} & \multirow{2}{*}{$\begin{array}{c}\begin{array}{c}\text { Standardized } \\
\text { Coefficients }\end{array} \\
\text { Beta }\end{array}$} & \multirow[t]{2}{*}{ sig. } \\
\hline & B & Std Error & & \\
\hline (Constant) & 4.774 & 377 & & 000 \\
\hline Target Contict & -280 & ogt & -338 & ooo \\
\hline $\begin{array}{l}\text { Post=Functional (Tax Auditor, Land and Building Tax } \\
\text { Appraisat, and Computer Program mers) }\end{array}$ & -385 & 151 & -258 & 012 \\
\hline Post-Account Representative Reviewers' objections & -477 & 161 & -415 & 004 \\
\hline Post=Other Subordinate Employeso & -432 & 199 & -345 & 031 \\
\hline Education Level & 049 & 005 & 002 & .453 \\
\hline Experience. & 107 & 051 & 193 & 039 \\
\hline Income & -155 & 108 & -184 & 151 \\
\hline
\end{tabular}

Hypothesis 8: organisational facilitation of target achievement is positively related to target commitment. The result from Table 11 has proved that Hypothesis 8 is true. There is a significant positive relationship between organisational facilitation of target achievement and target commitment $(\beta=0.445)$. There are two control variables which show a significant relationship 
with target commitment (employee position and level of income). Furthermore, the important significant factor is that the relationship helps to explain around $30.2 \%$ (adjusted R2=0.302) of the variance in respondents' scores. Thus, the results show a similar statement to Hypothesis 8 .

Table 11:

Relationship Between Organisational facilitation of target achievement and Target Commitment

\begin{tabular}{|c|c|c|c|c|}
\hline \multirow[t]{2}{*}{ Modet } & \multicolumn{2}{|c|}{$\begin{array}{l}\text { Unstandardized } \\
\text { Coefficients }\end{array}$} & \multirow{2}{*}{\begin{tabular}{|c|}
$\begin{array}{c}\text { Standsardined } \\
\text { Coefficients }\end{array}$ \\
Beta
\end{tabular}} & \multirow[t]{2}{*}{ Sig. } \\
\hline & B & 5td Error & & \\
\hline 1 (Constant) & 3.128 & 358 & & .000 \\
\hline Organis ational Facilitation Target Achievem ent & 367 & 056 & 445 & 000 \\
\hline $\begin{array}{l}\text { Post=Functional (Tax Auditor, Land and Building Tax } \\
\text { Appraisal, and Computer Programm ers) }\end{array}$ & -433 & 141 & -290 & .003 \\
\hline Post-Account Representative/Reviewers' Objections & -695 & 148 & -605 & .000 \\
\hline Post-Other Subondinate Em ployee & -541 & 188 & -432 & 004 \\
\hline Education Level & 007 & 062 & 009 & 909 \\
\hline Experience & 078 & 049 & 141 & .110 \\
\hline Income & -220 & 102 & -261 & 032 \\
\hline
\end{tabular}

Hypothesis 9: dysfunctional effects of targets are negatively related to target commitment. The result from the survey as shown in Table 12, gives the same result as the hypothesis. There is a significant negative relation between dysfunctional effects of targets and target commitment $(\beta=-0.567)$. The strength of correlation between these two variables is the highest among other variables, a high level of coefficient of determination, which is $41.3 \%$ (adjusted R2 $=0.413$ ). This means that increasing the level of dysfunctional effects of targets will significantly decrease the level of target commitment. However, the effect of control variables in this relationship is only significant for employee position and, just like other hypotheses, the level of target commitment for manager position is the highest among other employee positions. Hence, from these findings, it supports Hypotheses 9. 
Table 12:

Relationship Between Dysfunctional effects of target and Target

Commitment

\begin{tabular}{|c|c|c|c|c|}
\hline \multirow[t]{2}{*}{ Model } & \multicolumn{2}{|c|}{$\begin{array}{l}\text { Unstandardizad } \\
\text { Coefficionts }\end{array}$} & \multirow{2}{*}{\begin{tabular}{|c|}
$\begin{array}{c}\text { Standardiasd } \\
\text { Coefficiants }\end{array}$ \\
Eota \\
\end{tabular}} & \multirow[t]{2}{*}{ Sing. } \\
\hline & B & Sted Error & & \\
\hline (Comstant) & 5.405 & 336 & & 000 \\
\hline Dysfunctional Effocts of Tagots & -505 & 050 & -.567 & 000 \\
\hline $\begin{array}{l}\text { Post=Funetional (Tax Auditor, Land and Building Tax } \\
\text { Appraisal, and Computer Program m ers) }\end{array}$ & $\approx 315$ & 131 & 211 & 017 \\
\hline Post-Account Represientatiwo/Reviewars' Objections & -4.48 & 138 & -388 & 001 \\
\hline Post=Other Subordinate Employee & -480 & 172 & $-3 a x$ & oos \\
\hline Education Levol & 090 & 057 & 113 & 114 \\
\hline Exporienco & 039 & 045 & 071 & 385 \\
\hline income & -161 & 093 & -191 & 085 \\
\hline
\end{tabular}

Hypothesis 10: target clarity is positively related to target commitment. Based on the result in Table 13, there is a significant positive relationship between target clarity and target commitment. The effect of target clarity to target commitment is the second highest $(\beta=0.524$, adjusted $\mathrm{R} 2=0.377 / 37.7 \%)$ after dysfunctional effects of targets. Moreover, there is only one control variable (level of education) which has not significant interaction in this relationship. Thus, the findings are equal with Hypothesis 10.

Table 13:

Relationship Between Target Clarity and Target Commitment

\begin{tabular}{|c|c|c|c|c|c|}
\hline & \multirow[t]{2}{*}{ Model } & \multicolumn{2}{|c|}{$\begin{array}{l}\text { Unstandardized } \\
\text { Coefficients }\end{array}$} & \multirow{2}{*}{$\begin{array}{c}\begin{array}{c}\text { Standardized } \\
\text { Coefficients }\end{array} \\
\text { Beta }\end{array}$} & \multirow[t]{2}{*}{ Sig. } \\
\hline & & B & Std Error & & \\
\hline \multirow[t]{8}{*}{1} & (Constant) & 2.217 & 383 & & .000 \\
\hline & Target Clanity & 525 & .064 & 524 & 000 \\
\hline & $\begin{array}{l}\text { Post=Functional (Tax Auditor, Land and Building Tax } \\
\text { Appraisal, and Computer Program mers) }\end{array}$ & -403 & 134 & -269 & 003 \\
\hline & Post=Account Representative $R$ Reviewers' Objections & -651 & .140 & -566 & 000 \\
\hline & Post=Other Subordinate Em ployee & -416 & 177 & -333 & 020 \\
\hline & Educetion Level & .058 & .058 & 073 & 321 \\
\hline & Experience & 092 & 046 & 166 & 046 \\
\hline & Income & -230 & .096 & -274 & .018 \\
\hline
\end{tabular}

Hypothesis 11: target difficulty is negatively related to target commitment. Table 14 shows that there is no significant relationship between target difficulty and target commitment $(\mathrm{sig} / \mathrm{p}=0.134)$. However, the interaction between employee position in this relationship still shows a significant effect. It is probably caused by the high level of target difficulty (average mean=3.73). 
Hence, the relationship between these categories in this study has not the same result as the hypothesis.

Table 14:

Relationship Between Target Difficulty and Target Commitment

\begin{tabular}{|c|c|c|c|c|}
\hline \multirow[t]{2}{*}{ Model } & \multicolumn{2}{|c|}{$\begin{array}{l}\text { Unstandardized } \\
\text { Coefficients }\end{array}$} & \multirow{2}{*}{$\begin{array}{c}\begin{array}{c}\text { Standardized } \\
\text { Coefficients }\end{array} \\
\text { Beta }\end{array}$} & \multirow[t]{2}{*}{ Sig. } \\
\hline & $B$ & Std. Error & & \\
\hline (Constant) & 3.814 & .409 & & .000 \\
\hline Target Difficulty & .093 & .062 & 115 & .134 \\
\hline $\begin{array}{l}\text { Post=Functional (Tax Auditor, Land and Building Tax } \\
\text { Appraisal, and Computer Programmers) }\end{array}$ & -488 & 158 & -326 & .002 \\
\hline Post=Account Representative/Reviewers' Objections & -686 & 168 & -597 & .000 \\
\hline Post=0ther Subordinate Em ployee & -.501 & 210 & -400 & .019 \\
\hline Education Level & .026 & .069 & .033 & .703 \\
\hline Experience & .100 & .055 & 180 & .070 \\
\hline Income & -170 & .114 & -202 & .137 \\
\hline
\end{tabular}

To interpret the result from this research, this section compares the findings from this research with the hypotheses. The comparison between the findings and the hypotheses is discussed in the following paragraph.

Hypothesis 1 expects the positive relation between supervisor support/participation with target commitment. This study finds the same result with the hypothesis, as discussed in Chapter 4. The findings from the value of average mean also show that supervisor support/participation level is quite high within the DGTemployees. This result supports Locke's (1996) research, which stated that subordinates' participation in setting a goal, enabled by the supervisor, can lead to higher goal commitment. Although supervisor support/participation is high but based on the open question, the supervisor has little scope to determine the target. This generates the level of target difficulty to become quite high. In order to increase target commitment within the DGT's employees, the government should listen to the input from employees throughout the DGT 
organisation when determining the target. Hence, supervisor support/participation can be optimal, because is positively related to target commitment.

This study finds that target stress significantly has a negative relationship with target commitment. Hence, the findings confirm Hypothesis 2. The researcher also discovers that the level of target stress within the DGT's employees is low (low average mean). Lindberg and Wincent (2011) stated that people with high commitment will have low stress in their job, because they have the experience to face the stress. This also supports the findings that experience is significantly related to target stress and target commitment. Moreover, these findings show that income and employee position are also significantly related with target commitment in the relationship with target stress. The employees with high-level salary are usually employees who have long service at the DGT. Hence, the experience is related to the income and also related with target commitment. Furthermore, the same result also showed in Bipp and Kleingeld's (2011) research, which found a negative relationship between these variables. Thus, the DGT should have a low-level target stress because it is negatively related to target commitment within the DGT's employees.

The third hypothesis states that target efficacy is positively related to target commitment. The same result also shows from the findings. The results are broadly consistent with those of Locke (1996), who stated that goal efficacy leads to higher goal commitment. The researcher also finds that target efficacy within the DGT's employees is moderate. This factor can be increased to have better target commitment, as many of the DGT's employees stated in the target efficacy questionnaire item that they have less job training to achieve the target. Hence, to increase target commitment within the DGT's employees, the DGT should give more training to the employees on how to achieve the target, as it is positively related to target commitment.

This research finds that there is a positive relationship between target rationale and target commitment. This result agrees with the statement in Hypothesis 4. This factor relates to feedback from the supervisor with reference to goal attainment. The finding in this study supports that of Klein et al. (1999), 
which reported a significant positive correlation between feedback (having a knowledge of results) and goal commitment. Furthermore, employee position, experience, and income as control variables have significant interaction in this model. Moreover, the DGT should have more rationale target because, based on the additional questions in the survey, the DGT do not have rationale target. Thus, to increase the level of target commitment within the DGT's employees, the DGT should have better target rationale because they positively related each other.

Hypothesis 5 states that use of target setting in performance appraisal is positively related to target commitment. The finding shows the same result as the hypothesis. The researcher also finds that this factor has a high level of average mean. This factor combination between participation and feedback has a positive relationship with target commitment (Klein et al., 1999). Moreover, only employee position and the level of income as control variables have a significant relationship in this model.

The sixth hypothesis is tangible rewards are positively related to target commitment. This study shows that these variables also positively related to each other. The result has support from Presslee et al. (2012), who found that tangible rewards could ignite higher goal commitment. In this relationship, the study finds that the level of tangible rewards is not too high. Hence, there is a possibility to increase it and it will also increase target commitment. Moreover, only one control variable (employee position) has significant interaction in this case. In conclusion, the DGT should give more tangible rewards in order to increase target commitment, because there is a positive relationship between tangible rewards and target commitment within the DGT's employees.

Hypothesis 7 indicates that target conflict is negatively related to target commitment. This hypothesis has support from Locke and Latham (1990), who said that goal conflict negatively influences goal commitment. The result of this study shows a similar result to the hypothesis. Furthermore, there are two control variables (employee position and experience) which have a significant relationship in this model. This study also finds that the DGT's employees have a low-level target conflict. This means that the DGT is already good in this factor 
and should maintain this condition, because there is a negative relationship between target conflict and target commitment.

This study has shown that there is a positive relationship between organisation facilitation of target achievement and target commitment. This result is consistent with Hypothesis 8. The same result shows in the study of Bipp and Kleingeld (2011), who showed a positive relationship between organisation facilitation of target achievement and goal commitment. This study also finds that the level of this target setting factor is not too high. The DGT can increase the level of target commitment, which gives more facilitation to achieve the target, because the greater the organisation facilitation of target achievement level, the higher the target commitment within the DGT's employees.

Hypothesis 9 states that dysfunctional effects of targets are negatively related to target commitment. This variable shows the biggest relationship among other variables in target setting. As mentioned in Chapter 2, dysfunctional effects of goals related to possible negative consequences of having goals (Kwan et al., 2013) and this causes a negative effect to goal attainment. People who have high target commitment have the determination to attain a goal and an unwillingness to abandon it (Klein et al., 1999; Locke and Latham, 1990). Based on these findings, the DGT's employees have a high level of target commitment. As a result, DGT's employees have a low level of dysfunctional effects of targets. This supports the discussion in the literature review concerning unintended consequences. The result also finds that the DGT's employees have low-level dysfunctional effects of targets (low average mean). It means that the DGT is already good in this factor and should maintain this condition to keep target commitment at a high level.

Hypothesis 10 states that there is a positive relationship between target clarity and target commitment. Based on the finding, this research supports the hypothesis. This finding also supports previous research, for instance, Locke (1996) said the specific and hard goal caused a higher commitment to the goal. Moreover, Bipp and Kleingeld (2011) found that the relationship between goal clarity and goal commitment is positive and quite significant $(\beta=0.34)$. This study 
also finds that the DGT's employees have high-level target clarity and it explains why they have a high level of target commitment.

The researcher finds that there is not a significant relationship between target difficulty and target commitment. This result is different from Hypothesis 11. Although the result from this study is different from the hypothesis, this finding has a support. Klein et al. (1999) also reported a nonsignificant corrected average relationship between goal difficulty and goal commitment. Moreover, they stated that there is a strong possibility for moderator, because it was indicated by low correlation and the wide variance across their study. This might also be due to of a possible curvilinear relationship between these two variables, as mentioned in literature review. Furthermore, this study also finds that the level of target difficulty in the DGT's employees is high. It relates to the theory that said goals of moderate difficulty were associated with higher commitment. From the open question, the researcher also has the support that the target within the DGT is unfair/unrealistic, which leads to high-level difficulty. Hence, in the case of the DGT's employees, there is a nonsignificant relationship between target difficulty and target commitment because the target is high. Therefore, it is better for the DGT to have a moderate target that can be achieved to increase the level of commitment to the target.

From all of the summary above, the researcher can answer the research question. Hence, the answer for the research question is the levels of target commitment within the DGT's employees are high. Moreover, there is target setting in the DGT where positive factors to target attainment have a positive effect on target commitment and the otherwise negative factors to target achievement have negative impact to target commitment.

\section{CONCLUSION}

The level of target commitment within the DGT is high. It is caused by the high level of factors which caused a positive effect on target attainment (supervisor support / participation, use of target setting in performance appraisal, 
and target clarity). On the other hand, low level of negative effects of target achievement (target stress, target conflict, and dysfunctional effects of targets) within the DGT's employees also causes a high level of target commitment among these personnel. It can be seen from the relationship between target setting factors and target commitment that there is a positive relationship only in the factors which have a positive impact to target attainment. Thus, supervisor support/participation, target efficacy, target rationale, use of target setting in performance appraisal, tangible rewards, organisation facilitation of target achievement, and target clarity as positive effects of target attainment, have a positive relation to target commitment. However, target setting factors, which have a negative impact on the target, also have a negative relationship with target commitment. Hence, target stress, target conflict, and dysfunctional effect of targets as negative factors to target achievement have a negative relationship with target commitment. Even though these factors are low, this study suggests that the DGT reducing these factors even further may lead increasing target commitment. Surprisingly, target difficulty does not have a significant relationship with target commitment. It is a strong possibility for moderator, because based on previous research, the relationship between target difficulty and target commitment was not significant, but when target difficulty becomes a moderator in the relationship between target commitment and performance, target difficulty becomes significant. The researcher also finds that target difficulty with the DGT's employees is high. This is also the cause of the relationship not being significant. Furthermore, the demographic variables as control variables show significant correlation with target commitment only in employee position, the level of education, experience, and the level of monthly income. From those four control variables, only employee position shows significant interaction in all relationships between target setting factors and target commitment, and manager position has the highest level of target commitment. This means that manager position within the DGT's employees is the most committed to the target among the other employee positions. On the other hand, the level of education does not show any significant interaction. Hence, this study contributes some findings to support 
previous research in terms of the relationship between target setting factors and target commitment.

There are several limitations suggested in the current study. First, this study uses a small sample size of the DGT's employees $(\mathrm{N}=165)$, which does not equal if compared with the total of the DGT's employees, which are 37,734 employees (Indonesian Ministry of Finance, 2016c). Thus, the sample might not represent the condition of the DGT, as a whole organisation. However, this study tries to minimalise this problem by using participants from different kinds of tax offices, in order to obtain more diversity in the representation of employees of the DGT. Second, subjective measurement methods cause a series of a potential problems, for instance, differing interpretation of reliability of the survey ( $\alpha$ coefficient). Every researcher has a different scale to measure the reliability of the survey. Hence, this study tries to minimise the risk by gathering support from other research which shares a similar opinion with the researcher, in order to make the analysis become valid. Finally, the probability of other authors conducting almost similar research to this study is not discussed in this research. Hence, the opinions and the results of other authors may have different findings from this study.

The results of this study also have implications for further research development in target setting theory. As target difficulty has not significant correlation with target commitment, This indicates the role of target difficulty as a moderator on target commitment. The role of target difficulty as a moderator on target commitment needs further research. Klein et al. (1999) indicated that target difficulty has a strong possibility as moderator on target commitment. Although the results of this study show a significant relationship between several target setting factors and target commitment, future research needs to investigate the relationship with different indicators from various sources. Another suggestion for further research is the subject of the research. As mentioned in the limitations of the study, this research uses a small sample size of employees of the DGT, so the results perhap do not represent the condition of the DGT organisation as a whole. Hence, further research needs to use a large sample of employees of the DGT, or 
to examine specific employees position in the DGT (e.g. Account Representative and Tax Auditor). Moreover, further research can also assess other public service organisations in Indonesia, for example, the Ministry of Finance, the Police Departement, and the state's company. Thus, this further research will provide various results concerning target setting theory within the public sector in Indonesia and can be related with the existence of the NPM. For instance, the correlation between target setting theory with the NPM in the public sector and the effect on public sector performance.

\section{REFERENCES}

Anderson, V. (2013). Research methods in human resource management, investigating a business issue. 3rd ed. London: Chartered Institute of Personnel and Development.

Bandura, A. and Cervone, D. (1983). Self-evaluative and self-efficacy mechanisms governing the motivational effects of goal systems. Journal of Personality and Social Psychology. 45, pp.1017-1028.

Bavelas, J. and Lee, E. S. (1978). Effect of goal level on performance: A trade-off between quantity and quality. Canadian Journal of Psychology. 32, pp.219-240.

Bipp, T. and Kleingeld, A. (2011). Goal-setting in practice: The effect of personality and perceptions of the goal-setting process on job satisfaction and goal commitment. Personnel Review. 40(3), pp.306-323.

Early, P. C., Connolly, T. and Ekergen, G. (1989). Goals, strategy development and task performance: Some limits on the efficacy of goal-setting. Journal of Applied Psychology. 74, pp.24-33.

Hood, C. (1995). The "New Public Management" In The 1980s: Variations on a Theme. Journal of Accounting, organisations and Society. 20(2/3), pp.93109.

Huber, V. L. (1985). Effects of task difficulty, goal-setting and strategy on performance of heuristic task. Journal of Applied Psychology. 70, pp.492504.

Indonesian Ministry of Finance. (2014). KMK 467 Tahun 2014. Jakarta: Home Office.

Indonesian Ministry of Finance. (2016). APBN 2016. [Online]. [Accessed 26 June 2016]. Available from: http://www.kemenkeu.go.id/apbn2016.

Kim, K., Park, H. W., Ko, J. S., Kim, Y. and Han, S. S. (2010). Finding Elite Voters in Daum View: Using Media Credibility Measure. In: Bresli, J. G., Burg, T. N., Kim, H. G., Raftery, T. and Schmidt, J. H. eds. Recent Trends and Development in Social Software. Germany: Springer, pp.3845.

Klein, H. J., Copper, J.T. and Monahan, C. A. (2013). Goals and Self-Efficacy as 
Mediators. In: Locke, E. A. and Latham, G. P. eds. New Development in Goal-setting and Task Performance. London: Routledge, pp.65-89.

Klein, H. J., Wesson, M. J., Hollenbeck, J. R. and Alge, B. J. (1999). Goal Commitment and the Goal-Setting Process: Conceptual Clarification and Empirical Synthesis. Journal of Applied Psychology. 84(6), pp.885-896.

Klein, H. J., Wesson, M. J., Hollenbeck, J. R., Patrick, M. W. and DeShon, R. P. (2001). The Assessment of Goal Commitment: A Measurement Model Meta-Analysis. Organisational Behaviour and Human Decision Processes. 85(1), pp.32-55.

Kwan, H. K., Lee, C., Wright, P. L. and Hui, C. (2013). Goals and Self-Efficacy as Mediators. In: Locke, E. A. and Latham, G. P. eds. New Development in Goal-setting and Task Performance. London: Routledge, pp.583-600.

Larbi, G. A. (1999). The New Public Management Approach and Crisis States. [Online]. [Accessed 26 June 2016]. Available from: http://www.unrisd.org/80256B3C005BCCF9/(httpPublications)/5F280B1 9C6125F4380256B6600448FDBB.

Latham, G. P., and Baldes, J. (1975). The "practical significance" of Locke's theory of goal-setting. Journal of Applied Psychology. 60, pp.122-124.

Latham, G. P., and Kinne, S. B. (1974). Improving job performance through training in goal-setting. Journal of Applied Psychology. 59, pp.187-191.

Latham, G. P., and Locke, E. A. (1975). Increasing productivity with decreasing time limits: A field replication of Parkinson's law. Journal of Applied Psychology. 60, pp.524-526.

Latham, G. P., and Yukl, G. A. (1975). Assigned versus participative goal-setting with educated and uneducated woodworkers. Journal of Applied Psychology. 60, pp.299-302.

Latham, G. P., Winters, D. and Locke, E. A. (1994). Cognitive and motivational effects of participation. Journal of Organisational Behaviour. 15, pp.4963.

Lee, C., Bobko, P., Earley, P. C. and Locke, E. A. (1991). An empirical analysis of a goal-setting questionnaire. Journal of Organisational Behaviour. 12(6), pp.467-482.

Lindberg, E., and Wincent, J. (2011). Goal Commitment and Performance: An Empirical Study Incorporating Role-Stress Literature to Reveal Functional and Dysfunctional Influences. Journal of Applied Social Psychology. 41(11), pp. 2634-2655.

Locke, E. A. (1967). Further data on the relationship of task success to liking and satisfaction. Psychological Reports. 20, pp.246.

Locke, E. A. (1968). Toward a theory of task motivation and incentives. Organisational Behaviour and Human Performance. 3, pp.157-189.

Locke, E. A. (1996). Motivation through conscious goal-setting. Applied and Preventive Psychology. 5, pp.117-124.

Locke, E. A. and Bryan, J. (1967). Performance goals as determinants of level of performance and boredom. Journal of Applied Psychology. 51, pp.120130.

Locke, E. A. and Latham, G. P. (1984). Goal-setting: A Motivational Technique 
that Works. New York: Prentice Hall.

Locke, E. A. and Latham, G. P. (1990). A Theory of Goal-setting and Tas Performance. New York: Prentice Hall.

Locke, E. A. and Latham, G. P. (2002). Building a Practically Useful Theory of Goal-setting and Tas Performance. American Psychologist. 57(9), pp.705717.

Locke, E. A. and Latham, G. P. (2013). Goals Setting Theory, 1990. In: Locke, E. A. and Latham, G. P. eds. New Development in Goal-setting and Task Performance. London: Routledge, pp.3-15.

Mento, A. J., Steele, R. P. and Karren, R. J. (1987). A Meta-Analytic Study of the Effects of Goal-setting on Task Performance: 1966-1984. Organisational Behaviour and Human Decision Processes. 39, pp.52-83.

Mitchell, T. R. and Daniels, D. (2003). Motivation. In: Borman, W. C., Ilgen, D. R. and Klimoski, R. J. eds. Comprehensive Handbook of Psychology: Industrial Organisational Psychology. New York: Wiley, pp.225-254.

Pallant, J. F. (2005). SPSS Survival Manual: A step by step guide to data analysis using SPSS for Windows (Version 12). 2nd ed. Sydney: Ligare.

PNB the International Law Firm. (2016). Overview Tax Indonesia. [Online]. [Accessed 26 June 2016]. Available from: http://www.pnblawfirm.com/overview-tax-indonesia.

Presslee, A., Vance, T.W. and Webb,A. (2016). The Effects of Reward Type on Employee Goal-setting, Goal Commitment, and Performance. [Online]. [Accessed 27 July 2016]. Available from: http://ssrn.com/abstract $=1656517$.

Saunders, M., Lewis, P. and Thornhill, A. (2016). Research Methods for Business Students. 7th ed. London: Pearson.

Smith, K., Locke, E. and Barry, D. (1990). Goal-setting, planning and organisational performance: An experimental simulation. Organisational Behavior and Human Decision Processes, 46, pp.118-134.

Steers, R. M. and Porter, L.W. (1974). The Role of Task-Goal Attributes in Employee Performance. Psychological Bulletin, 81, pp.434-452.

Tubbs, M. E. (1986). Goal-Setting: A Meta-Analytic Examination of the Empirical Evidence. Journal of Applied Psychology. 71, pp.473-483.

Verbeeten, F. H. M. and Spekle', R. F. (2015). Management Control, ResultsOriented Culture and Public Sector Performance: Empirical Evidence on New Public Management. Organisation Studies. 36(7). pp. 953-978.

Verma, J. P. (2013). Data Analysis in Management with SPSS Software. [Adobe Acrobat Reader DC]. India: Springer.

Wood, R., Mento, A. and Locke, E. (1987). Task complexity as a moderator of goal effects. Journal of Applied Psychology. 17. pp.416-425.

Yearta, S.K., Maitlis, S. and Briner, R. B. (1995). An exploratory study of goalsetting in theory and practice: A motivational technique that works?. Journal of Occupational and Organisational Psychology. 68.pp.237-252. 